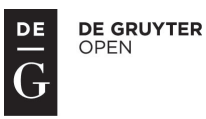

\title{
EFFECTIVEness OF MARKETING MiX ACTIVITIES IN ENGINEERING COMPANIES IN THE CZECH REPUblic
}

\author{
František Milichovsk $\dot{y}^{1}$
}

\begin{abstract}
The effectiveness of marketing activities has become important, especially in the industrial environment. In an industrial environment, there is a prerequisite for the success of strategic marketing objectives in relation to corporate strategy. The main aim of the paper is to determine whether the realization of marketing activities is influenced by corporate size. For this reason, a questionnaire survey was used, focusing on engineering companies operating in the Czech Republic. To process the results of the questionnaire survey, both basic types of descriptive statistics and Pearson's chi-square test were used on the selected dataset. The data were processed using the statistical program IBM SPSS Statistics 22. The conclusions provide characteristics of the limitations of research and its potential further direction.
\end{abstract}

\section{Keywords}

Marketing Mix, Marketing Effectiveness, Corporate Size, Engineering

\section{Introduction}

In industrial companies, it is important to focus not only on the present, but also on the future, because the results of previous periods could be misrepresentative. Industry has become a field with meaningful impact on the economic and social situation in the Czech Republic. Industrial production is a significant part of social-economic and public stability, especially in the manufacturing industry.

It is obvious that marketing processes have become a complex set of activities that create the market and market system. Because of the effective application of individual marketing processes (in establishing a market position and entering potential markets), it is necessary to incorporate all factors and connections into one's own processes as a way of creating a single compact system. Accurate strategic marketing policies help to state and target

${ }^{1}$ Brno University of Technology, Faculty of Business and Management, Kolejní 2906/4, 61200 Brno, Czech Republic. E-mail: milichovsky@fbm.vutbr.cz. 
product offer with the appropriate tool to achieve a defined market segment (Chorafas, 2011).

The realization of marketing activities in the right way could prepare the background for strengthening own market position and market competitiveness, which could lead to improving the economic environment in the Czech Republic, and in comparison with other foreign companies worldwide (Koudelková, 2013).

From the point of view of the final market (industrial, consumer) there are differences in the realization of individual marketing activities. Forsyth (2007) describes the closed connection between corporate size and the realization of marketing activities. It is therefore necessary to perform adequate research.

\section{Main text}

The industrial market has become a much more complex process, which introduces requirements for the increased use of the correct tools. In connection with the ongoing economic crisis, there are new opportunities for corporate innovation, which it is important to measure (Drugä, 2009). Modern businesses are dependent on the control of intangible assets such as brand, intellectual property, human capital or market relationships (Ambler, 2002). In order for the marketers of these abstract elements to determine whether they are effective or not, they must be able to convert the results into financial terms (Kotler, Keller, 2006). According to Zahay and Griffin (2010), the main problem is that companies do not measure their own performance on the customer level. Enterprises operating in industrial markets are much more sensitive to sales volume than are businesses in consumer markets. This has an impact on misunderstanding the results obtained from previous successful marketing programs.

Measuring the performance of customers is usually dependent on the area of corporate activity, especially in industry. Barwise and Farley (2004) state that those companies which use or plan to use indicators for measuring, tend to use more diverse measures.

Performance measurement can be defined as a system by which a company monitors its daily operations and evaluates whether it is attaining its objectives (Lebas, 1995; Lima, Costa, Angelis, 2009). A series of indicators that properly reflects company performance objectives should be set up to fully utilize the function of performance measurement. These indicators can be quantifiable or unquantifiable.

Performance measurement is an important tool for sustainable management. Well-defined indicators can potentially support the identification of current and desired performance and provide us with information on the progress of individual performances. In addition, it can be a link between strategy and management, thereby promoting the establishment and implementation of initiatives related to the improvement of the company (Maria, 2009; Muchiri et al., 2010; Hornungová, 2014b).

Performance measurement supports corporate day-to-day activities to reach strategic goals. However, it is necessary to use the correct method to derive the indicators to be used in engineering companies. In those companies, there are not usually requirements to measure performance and effectiveness in any other way than in financial figures. All indicators 
used could be contained in a system of key performance indicators (KPI). This system become a strategic tool to measure accurate performance, find appropriate results and interpret them (Zaherawati et al., 2011; Kerzner, 2011).

These indicators are focused on corporate areas that need to be monitored and measured. Individual indicators could have different information and could be divided into (Hornungová, 2014a; Parmenter, 2010):

- Key Result Indicators - contains information about results attained and whether the company is going in the right direction;

- Result Indicators - notes what has been done;

- Performance Indicators - announces what has to be done;

- Key Performance Indicators - describes what is necessary to increase performance and improve results.

As Marinič (2008) and Parmenter (2010) mentioned, once the correct key indicators that reflect the goals of the company (those that can be measured) have been defined, it is possible to use these performance indicators as tools for performance measurement. This depends on how entities inside and outside the company approach the performance process, and why they monitor their own performance. Measurements can be divided according to the type of key indicators and results. The measurable key indicators should be divided, according to their essence, into several groups (Smith, 2008; Zaherawati et al., 2011; Samsonowa, Buxman, Gerteis, 2009).

Marketing activities could be defined from different perspectives. Siu (2002) and Mohamad, Ramayah and Puspowarsito (2011) describe marketing activities as the set of areas in which a company has to be interested if it is to effectively satisfy customers' needs. A company's realisation of its own marketing activities has become a wide area - from the point of view of marketing mix, there are different approaches for how to fulfil individual requirements. The whole marketing mix helps to manage knowledge and supports corporate processes (Webb et al., 2011).

Individual marketing activities are blending together and influencing the others. They cannot be classified into only one group. It is possible to see marketing activities from different perspectives. Among the most important aspects, which could be applied in a company are: (1) marketing activities from the point of view of time, (2) marketing activities from the point of view of marketing mix, and (3) marketing activities from the point of view of the market. For the purpose of this article, the perspective of the marketing mix was chosen.

The success of individual marketing activities could be validated as the effectiveness of realized marketing activities. A suitable approach focuses on those activities which have a direct impact on customers, primarily on the product and forms of marketing communication. However, the whole process of marketing effectiveness needs to undergo a process of continuous improvement, especially in times of economic and financial crisis. Manufacturers want to achieve that with their own marketing audits, which identifies the major shortcomings of the current approach to measuring effectiveness (Christian, 1959). 
According to Forsyth (2007) and Mathur (2008), the size of a company impacts on market competitiveness. Competitiveness in the industrial market requires a suitable decisionmaking process (decision speed, shortening the response time), which is focused on geographical segments. Small companies realize marketing activities in different ways than large companies.

The effectiveness of marketing activities should be defined as return of funds invested into these activities. There are various ways to measure these activities in terms of evaluation (Kotler, Keller, 2006, 2012). For measuring, several groups of marketing indicators are applied, which help to quantify possible trends, dynamics or characteristics (Farris et al., 2010). Measuring the performance of marketing activities becomes a business process that provides performance feedback on the results of realized marketing activities.

Business performance is becoming an important part of corporate budgeting and performance compensation and promotion (Clark, Abela, Ambler, 2006; Ginevičius, Podvezko, Ginevičius, 2013; Kožená, Chládek, 2012).

Marketing indicators (as a tool to find effectiveness) could reach the highest level of priority in the whole business environment, because they create a competitive advantage. The reason should be dissatisfaction with the traditional way of measuring marketing activities, connected with accounting, corporate cost-trends, or the rapid progress of IT (Seggie, Cavusgil, Phelan, 2007).

Nowadays, it is possible to use many different methods as marketing indicators. These methods help track business performance through data collection from individual marketing activities, such as marketing campaigns, marketing channels or customer responsiveness (Li, 2011).

\section{Methodology}

The first part of the paper presents main the secondary information as processed by many scientific articles and literature. The next, and main part of the paper, is to introduce research data that were obtained from primary research. All the primary research was focused on the performance evaluation of companies (in the area of marketing performance) in the Czech Republic.

According to the defined theoretical background, there was the stated hypothesis that "measurement of marketing activities is dependent on corporate size". Part of the primary research was carried out to test this hypothesis.

The primary research was designed by means of a questionnaire survey focused on engineering companies in the Czech Republic in 2013. The questionnaire was compiled on the basis of achieved theoretical knowledge, defined areas of solved problems and specific objectives, so that the results obtained could contribute to the setup of KPI for the companies in the selected area. The conditions for choosing the companies were a combination of:

- geographical location (the Czech Republic),

- classification of economic activities according to CZ-NACE, reduced to chosen engineering area: 
- 28 - Manufacture of machinery and equipment;

- 29 - Manufacture of motor vehicles, trailers and semi-trailers;

○ 30 - Manufacture of other transport equipment.

The results and discussion of the paper are based on the analysis of secondary sources and a selected part of the questionnaire survey, which are involved in measuring the performance of Czech companies. To process the results of the questionnaire survey, both the basic types of descriptive statistics and a Pearson Chi-square test on the selected data set were used. The data were processed by using the statistical program IBM SPSS Statistics 23.

The basic population of all companies in the chosen industry groups is 7,329 companies (according to the list of companies in the Czech Statistical Office. The sample population was created from 366 respondents that were chosen in a random manner from the company data set. The number of respondents that sent back answered questionnaires was 147 (return effectiveness of $40.16 \%$ ).

Using appropriate algorithms, we are able to reveal the structure of the studied set of objects and individual objects classified. Table 1 shows the distribution of sample population (relative and absolute values) and basic population (theoretical relative values), representing the group of respondents on which the questionnaire survey focused on (according to CZ-NACE classification and corporate size). According to two paired t-test as significance of both variances of sample population of size and CZ-NACE group, it is possible to say that there are no differences between individual variances (formula 1).

$$
|t|=3,059>t_{0,05(3,3)}=1,943
$$

Table 1: Structure of respondents according to corporate size and CZ-NACE classification

\begin{tabular}{|l|l|ccc|c|}
\hline \multicolumn{2}{|c|}{} & \multicolumn{3}{|c|}{ Corporate size } & \multirow{2}{*}{ Total } \\
\cline { 3 - 5 } & & $\begin{array}{c}\text { Small } \\
\text { companies }\end{array}$ & $\begin{array}{c}\text { Medium } \\
\text { companies }\end{array}$ & $\begin{array}{c}\text { Large } \\
\text { companies }\end{array}$ & \\
\hline Group 28 & Absolut & 66 & 34 & 11 & 111 \\
& Relative & $59.46 \%$ & $30.63 \%$ & $9.91 \%$ & $100 \%$ \\
& Theoretical relative & $63.52 \%$ & $24.75 \%$ & $11.73 \%$ & $100 \%$ \\
\hline Group 29 & Absolut & 13 & 5 & 5 & 23 \\
& Relative & $56.52 \%$ & $21.74 \%$ & $21.74 \%$ & $100 \%$ \\
& Theoretical relative & $65.13 \%$ & $25.38 \%$ & $12.03 \%$ & $100 \%$ \\
\hline Group 30 & Absolut & 6 & 3 & 4 & 13 \\
& Relative & $46.15 \%$ & $23.08 \%$ & $30.77 \%$ & $100 \%$ \\
& Theoretical relative & $63.59 \%$ & $24.78 \%$ & $11.74 \%$ & $100 \%$ \\
\hline Total & & 85 & 42 & 20 & \\
\hline
\end{tabular}

Source: own research 


\section{Results}

The first part of the paper presents the main secondary information as processed by many scientific articles and the literature. The main part of the paper contains research data obtained from primary research focused on marketing performance in Czech engineering companies.

Individual parts of the marketing mix could have different significance. Therefore, the main hypothesis was divided into areas covering four parts of the marketing mix (product, price, promotion, place). After analysis of descriptive statistics, it is obvious that companies are focused mainly on product policy and price policy. These areas could therefore be accepted as meaningful factors for the industrial environment (Table 2).

The questionnaire was focused on whether companies monitor their own effectiveness in individual parts of the marketing mix. Possible answers were (1) never used, (2) rarely used (1-2 times per year), (3) Occasionally used (3-6 times per year), (4) Regularly used (7 and more times per year).

The scale for the answers was from 0 to 3 . The means of the individual parts show that companies mainly monitor activities of products, price and place, and use adequate indicators occasionally (3-6 times per year). Promotion activities are rarely measured (1-2 times per year).

Table 2: Descriptive statistics of defined variables

\begin{tabular}{|l|cccc|}
\hline & Product & Price & Promotion & Place \\
\hline Mean & 1.68 & 1.61 & 0.76 & 1.50 \\
Median & 2.00 & 2.00 & 1.00 & 2.00 \\
Minimum value & 0 & 0 & 0 & 0 \\
Maximum value & 3 & 3 & 3 & 3 \\
Standard deviation & 0.860 & 0.807 & 0.698 & 0.887 \\
Variance & 0.740 & 0.651 & 0.488 & 0.786 \\
\hline
\end{tabular}

Source: own research

During further analysis, a test of dependency of variables was carried out possibility of influence. In order to establish the dependency test, statistical testing using a chi-square test was used.

According to the defined theoretical background, there was a stated hypothesis that " $m e$ asurement of marketing activities is dependent on corporate size". To verify this premise, a pivot table was created for two questions in the questionnaire survey:

- Size of company - Number of employees on 1.1.2013;

- From the point of view of marketing performance/effectiveness, do you track policy for product, price, promotion and place?

According to statistical evaluation, the stated hypothesis had to be transformed into a statistical formulation as follow (the individual elements of the marketing mix were changed): 
- $\mathrm{H}_{0}$ : Effectiveness of product activities is not dependent on corporate size.

- $\mathrm{H}_{1}$ : Effectiveness of product activities is dependent on corporate size.

The results of the dependency test are provided in Table 3, which examines the dependency between corporate size and influence of elements in the marketing mix. The results of the dependency examination in individual variable categories are depicted in the following results of Pearson's chi-square test.

Table 3: Pearson's test of the relationship between corporate size and effectiveness of marketing activities

\begin{tabular}{|l|l|c|c|}
\hline & & $\begin{array}{c}\text { Pearson } \\
\text { Chi-Square }\end{array}$ & $\begin{array}{c}\text { Pearson's } \\
\text { contingency } \\
\text { coefficient }\end{array}$ \\
\hline Price activities & Value & 25.881 & 0.387 \\
& Approx. Sig. & 0.000 & \\
\hline Product activities & Value & 12.808 & 0.283 \\
& Approx. Sig. & 0.046 & \\
\hline Promotion activities & Value & 22.786 & 0.366 \\
& Approx. Sig. & 0.001 & \\
\hline Place activities & Value & 9.544 & 0.247 \\
& Approx. Sig. & 0.145 & \\
\hline
\end{tabular}

Source: own research

Maintaining the $\%$ reliability of the test, established value was compared with 0.05 , which represents a 5\% reliability level. The established alpha values of individual variables are:

- Corporate size and product policy: $\alpha=0,046$

- Corporate size and price policy: $\alpha=0,000$

- Corporate size and promotion policy: $\alpha=0,001$

- Corporate size and place policy: $\alpha=0,145$

According to the observed values of the Pearson's chi-square tests, two decisions are obvious. There are dependencies between corporate size and (1) product activities, (2) price activities, and (3) promotion activities. The results show no dependence between corporate size and place activities. Subsequently, the degree of such dependency was examined. To that end, the intensity of dependency determined by means of contingency coefficient as per formula (2) was used.

$$
C_{p}=\sqrt{\frac{\chi_{p}^{2}}{\chi_{p}^{2}+n}}
$$

where: $C_{p}$ - contingency coefficient;

$n$ - number of cases;

$\chi_{p}^{2}-$ Pearson's chi-square. 
The intensity of dependency ranges between $<0 ; 1\rangle$. That means that the higher the absolute value, the greater the intensity of dependency. The values of variables describe their intensity:

- Intensity of dependence between corporate size and product policy: $C_{p}=0,283$

- Intensity of dependence between corporate size and price policy: $C_{p}=0,387$

- Intensity of dependence between corporate size and promotion policy: $C_{p}=0,366$

All of these values of intensity incline to be medium rather than low. The individual variables include groups of indicators usually used in engineering companies in the Czech Republic. For measuring effectiveness in a company, a lot of possible indicators exist (see Baroudi, 2010). In connection with the realization of marketing activities, the respondents marked which indicator groups are used in their companies for measuring marketing effectiveness. The respondents marked these indicators by using frequency of measuring during the year. Possible frequencies of measuring were: (1) Never (no measurement per year); (2) Rarely (1-2 per year); (3) Occasionally (3-6 per year); (4) Periodically (7 and more per year). The purpose of the research was not to observe exact values of used indicators, but to find out which indicators they use and how often. All indicators could be divided into two groups (one point of view): financial and nonfinancial. Financial results are self-explanatory to the reader. For non-financial indicators, it is necessary to have additional information about the context of the values gained.

In Table 4 there are descriptive statistics showing indicator usage in companies (possible range was from 0 to 3). Engineering companies, which were those who participated in the research, have mainly focused on traditional indicators. The most used traditional indicators could be accepted as being quality of products, earned profit, dealer's indicators and indicators of delivering (see Table 4).

Table 4: Indicator groups in individual variables

\begin{tabular}{|llccc|}
\hline Variable & Groups & Mean & Variance & Standard deviation \\
\hline Place & Indicators of delivering & 2.27 & 0.607 & 0.779 \\
& Indicators of packaging & 1.97 & 0.965 & 0.982 \\
\hline Product & Quality indicators & $\mathbf{2 . 2 0}$ & 0.379 & 0.615 \\
& Customer's indicators & 1.52 & 0.566 & 0.753 \\
& Value added indicators & 1.32 & 0.918 & 0.958 \\
& Employee's indicators & 1.21 & 0.757 & 0.870 \\
& Process's indicators & 1.16 & 0.558 & 0.747 \\
\hline Price & Profit indicators & $\mathbf{1 . 7 4}$ & 0.768 & 0.877 \\
& Customer's indicators & 1.68 & 0.781 & 0.884 \\
& Performance indicators & 1.21 & 0.784 & 0.885 \\
& Business indicators & 0.63 & 0.578 & 0.760 \\
& Shareholder's indicators & 0.44 & 0.316 & 0.562 \\
\hline
\end{tabular}

Continued on next page 


\begin{tabular}{|llccc|}
\hline Variable & Groups & Mean & Variance & Standard deviation \\
\hline Promotion & Dealer's indicators & $\mathbf{1 . 0 3}$ & 0.882 & 0.939 \\
& E-marketing indicators & 0.60 & 0.612 & 0.782 \\
& PR indicators & 0.50 & 0.594 & 0.771 \\
& Indicators of web access & 0.31 & 0.460 & 0.679 \\
\hline
\end{tabular}

Source: own research

\section{Conclusion}

The engineering industry is one of the most important sectors and is characterized by a wide range of products and close connections with other fields (mainly because of globalization and technology progress). The globalization process brings with it requirements for quality, price and production volume that are usually in conflict (Ambler, 2002). Therefore, all companies must monitor the effectiveness of the implementation of marketing activities. The reason for this monitoring is that is not appropriate to carry out any activity without measuring its impact on the enterprise (Halachmi, 2005).

From the point of view of the realization of marketing activities, there are several difficulties in the corporate marketing concept (of course in the whole group). Because of growing the company and the whole group, at the same time there are a growing number of managing subjects in the decision-making process. That could create "ambiguity" in providing marketing information to the production department - product range offer (Tomek, Vávrová, 2011; Bruckner et al., 2012).

The stated hypothesis was divided into four partial elements according to marketing mix. Pearson's chi-square test was used to evaluate the hypothesis.

According to the results, it is possible to state that there exist dependencies between corporate size and product-, price- and communication policies. Distribution policy and its activities is realized with no reflection on the size of the company.

Actually, individual elements of the marketing mix are important for each company. Unfortunately, all marketing activities are connected with product and its R\&D process. Distribution is also connected with product, but it is only one marketing area that provides to the producer/distributor a kind of flexibility on reaching the final customer. Therefore, an effective distribution policy helps increase the competitiveness of Czech companies.

\section{References}

Ambler, T. (2002). Market Metrics: What Should We Tell the Shareholders? The Journal of Risk Finance, 10(1), 47-50.

Baroudi, R. (2010). KPI mega Library. Scots Valley. Rachard Baroudi.

Barwise, P., Farley, J. U. (2004). Marketing Metrics: Status of Six Metrics in Five Countries. European Management Journal, 22(3), 257-262.

Bruckner, T. et al. (2012). Tvorba informačních systémů: Principy, metodiky a architektury. Praha: Grada Publishing. 
Chorafas, D. M. (2011). Business marketing, and management: Principles for IT and engineering. Boca Raton: Taylor \& Francis.

Christian, R. C. (1959). Seventeen Ways to Improve Marketing Effectiveness. Journal of Marketing, 23(1), 301-302.

Clark, B. H., Abela, A. V., Ambler, T. (2006). An Information Processing Model of Marketing Performance Measurement. Journal of Marketing Theory and Practice, 14(3), 191-208.

Drugä, P. (2009). Competitive strategies within industrial markets. Platforma/Laborator de Analize Statisticesi Previziune a fenomenelor Economico-socialesi cercetari de marketing, 4, 17-20.

Farris, P. W., Bendle, N. T., Pfeifer, P. E., Reibstein, D. J. (2010). Marketing Metrics: The Definitive Guide to Measuring Marketing Performance (2nd ed.). New Jersey: Pearson Education.

Forsyth, P. (2007). Demystifying Marketing: A Guide to the Fundamentals for Engineers. London: The Institution of Engineering and Technology.

Ginevičius, R., Podvezko, V., Ginevičius, A. (2013). Quantitative Evaluation of Enterprise Marketing Activities. Journal of Business Economics and Management, 14(1), 200-212. Halachmi, A. (2005). Performance measurement is only one way of managing performance. International Journal of Productivity and Performance Management, 54(7), $502-516$.

Hornungová, J. (2014a). Factor Analysis: An Instrument for Selection of Social Performance Factors. Revista de Metodos Cuantitativos para la Economia y la Empresa, 17(6), 121-136.

Hornungová, J. (2014b). Development of Concepts and Models of Performance Evaluation from the 19th Century to the Present. DANUBE: Law and Economics Review, 5(2), $143-154$.

Kerzner, H. (2011). Project Management Metrics, KPIs, and Dashboards: A Guide to Measuring and Monitoring Project Performance. New Jersey: John Wiley \& sons.

Koudelková, P. (2013). Přístupy českých podnikatelů $\mathrm{k}$ inovacím v malých a středních podnicích. Trendy ekonomiky a managementu, 7(15), 68-74.

Kotler, P., Keller, K. L. (2006). Marketing Management (12th ed.). New Jersey: Pearson Education.

Kotler, P., Keller, K. L. (2012). Marketing management (14th ed.). New Jersey: Pearson Education.

Kožená, M., Chládek, T. (2012). Company Competitiveness Measurement Depending on its Size and Field of Activities. Procedia - Social and Behavioral Sciences, 58(12), 1085-1090.

Lebas, M. J. (1995). Performance Measurement and Performance Management. International Journal of Production Economics, 41(1), 23-35.

Li, L. Y. (2011). Marketing Metrics Usage: Its Predictor and Implications for Customer Relationship Management. Industrial Marketing Management, 40(1), 139-148.

Lima, E. P., Costa, S. E. G., Angelis, J. J. (2009). Strategic Performance Measurement Systems: A Discussion about Their Roles. Measuring Business Excellence, 13(3), 39-49. 
Maria, B. (2009). Information System for Modeling Economic and Financial Performances. Annals of the University of Oradea, Economic Science Series, 18(4), 902-907.

Marinič, P. (2008). Plánování a tvorba hodnoty firmy. Praha: Grada Publishing.

Mathur, U. C. (2008). Business to Business Marketing. New Delhi: New Age International. Mohamad, O., Ramayah, T., Puspowarsito, H. (2011). Incidence of Marketing Activities in Medium-Sized Manufacturing Firms in Indonesia: Comparing Export Intenders and Non-Export Intenders. International Journal of Business and Society, 12(1), 89-102.

Muchiri, P. N., Pintelon, L., Martin, H., De Meyer, A. M. (2010). Empirical Analysis of Maintenance Performance Measurement in Belgian Industries. International Journal of Production Research, 48(20), 5905-5924.

Parmenter, D. (2010). Key Performance Indicators: Developing, Implementing, and Using Winning KPIs. New Jersey: John Wiley \& Sons.

Samsonowa, T., Buxmann, P., Gerteis, W. (2009). Defining KPI Sets for Industrial Research organizations - A Performance Measurement Approach. International Journal of Innovation Management, 13(2), 157-176.

Seggie, S. H., Cavusgil, E., Phelan, S. E. (2007). Measurement of Return on Marketing Investment: A Conceptual Framework and the Future of Marketing Metrics. Industrial Marketing Management, 36(6), 834-841.

Siu, W. (2002). Marketing Activities and Performance: A Comparison of the InternetBased and Traditional Small Firms in Taiwan. Industrial Marketing Management, 31(2), 177-188.

Smith, D. (2008). Implementing Indicators for IT Service Management. Van Haren Publishing.

Tomek, G., Vávrová, V. (2011). Marketing: Od myšlenky k realizaci (3rd ed.). Praha: Professional Publishing.

Webb, J. W., Ireland, D. R., Hitt, M. A., Kistruck, G. M., Tihanyi, L. (2011). Where is the Opportunity without the Customer? An Integration of Marketing Activities, the Entrepreneurship Process and Institutional Theory. Journal of the Academy of Marketing Science, 39(4), 537-554.

Zahay, D., Griffin, A. (2010). Marketing Strategy Selection, Marketing Metrics, and Firm Performance. Journal of Business \& Industrial Marketing, 25(2), 84-93.

Zaherawati, Z., Mahazril, A. Y., Zuraini, Y., Nazni, N., Mohd Zool Hilmie, M. S., Zuriawati, Z. (2011). Key Performance Indicators (KPIs) in the Public Sector: A Study in Malaysia. Asian Social Science, 7(7), 102-107. 